Fikrah: Jurnal Ilmu Aqidah dan Studi Keagamaan

issn 2354-6147 eissn 2476-9649

Tersedia online di: journal.stainkudus.ac.id/index.php/Fikrah

DOI: http://dx.doi.org/10.21043/fikrah.v4i2.1633

\title{
Menguji Kebenaran Local Wisdom sebagai Modal Toleransi: Studi Kasus di Kudus
}

\author{
Moh Rosyid \\ STAIN Kudus \\ mrosyid72@yahoo.co.id
}

\begin{abstract}
Abstrak
penelitian ini sebagai upaya mencari fakta apakah local wisdom yang diwariskan oleh Sunan Kudus (pelarangan menyembelih sapi) hingga kini dapat menyebabkan terwujudnya toleransi di Kudus? Realitasnya tak terbukti. Riset tahun 2015 ini data diperoleh dengan wawancara, dokumentasi, observasi, forum group discussion dengan umat minoritas dan mayoritas dengan analisis deskriptif kualitatif. Faktanya, konflik antar-umat beragama secara terbuka atau terselubung sering terjadi. Sebagaimana penutupan tempat ibadah yang juga rumah hunian/ lahan bisnis, dalihnya tak menaati aturan dalam PBM Menag dan Mendagri, pemisahan makam muslim dan Budha. Di sisi lain (1) penggunaan pengeras suara di tempat ibadah yang melebihi jam tayang, (2) penghentian khalwatan karena sentimen dan rebutan santri, (3) pembubaran louncing Majelis Tafsir al-Quran (MTA), dan (4) keberadaan Jemaat Ahmadiyah Indonesia di Colo Dawe yang rentan terpicu konflik. Fakta itu sebagai penanda bahwa local wisdom tak selalu menjadi penggerak toleransi kehidupan bermasyarakat seagama, apalagi lintas agama.
\end{abstract}

Kata Kunci: Kearifan lokal, komitmen, konflik, toleransi, komitmen 


\begin{abstract}
This research attempts at finding the fact whether local wisdom pioneered by Sunan Kudus (ban on cow slaughter) up to the present time can lead to the realization of tolerance in Kudus. The reality is not proven. The data were gathered from interviews, documentation, observation, group discussion forum with the minority and majority people using qualitative descriptive analysis. In fact, inter-religious conflicts openly or covertly occurred. As the closure of places of worship that also becomes houses residential / business area, the excuse does not comply with the rules in the PBM of Religious ministry and Internal Affairs Ministry, the separation of Muslim and Buddhist tomb. On the other hand, (1) the use of loudspeakers in places of worship that exceeds show times, (2) termination of khalwatan as sentiment sense and seizure of students, (3) dissolution of louncing in Assembly Tafsir al-Quran (MTA), and (4) the existence of Ahmadiyah in Colo Dawe was vulnerable triggered the conflict. The fact that local wisdom is not always lead to the same religion of tolerance in community life, especially the religious borders.
\end{abstract}

Keywords: Local Wisdom, Commitment, Conflict, Tolerance, Commitment

\title{
Pendahuluan
}

Islam, melalui al-Qur'an menganjurkan kepada umat Islam supaya berlombalombalah dengan cara yang baik (QS. Al-Maidah). Ajaran dalam Islam tersebut yang menganjurkan supaya supaya berlomba dengan cara yang baik ini pada tataran realitas kurang mendapat perhatian bagi muslim sendiri. Hal ini karena pemaknaannya disesuaikan dengan kepentingan kelompoknya. Dampaknya, perbedaan yang sudah didesain Tuhan kadang menjadi sumber konflik karena masing-masing individu atau kelompok mengedepankan emosi dan menomorsekiankan perasaan. Hal yang terjadi adalah keinginan untuk memaksakan diri atau kelompok terhadap keinginannya meskipun bertentangan dengan hati nurani, hukum positif, dan syariah. Bila pemaksaan terbiasa maka yang muncul dalam benaknya adalah terjadi pembenaran yang dipaksakan.

Perbedaan suku, agama, ras, dan antar-golongan (SARA) merupakan desain Tuhan. Perbedaan tersebut bisa memunculkan rasa kasih sayang (rahmah) bila saling memahami, terutama bila memahami kata 'agama'. Kata agama merujuk Kamus Bahasa Arab Lisan al-Arab karya Ibnu Manzur (2005) memiliki beragam makna. Dinamika maknanya menurut Sayed Muhammad Naquib al-Attas, dalam bahasa Arab din dari kata dasar dayana bisa berubah menjadi dayn berarti berutang, maksudnya orang beragama berkewajiban (daynunah). Kata dayana bisa menjadi idanah berarti berkeyakinan sebagai modal dasar (ruh) kewajiban, 
orang yang menjalankan kewajiban disertai dorongan keyakinan. Kata dayana menjadi maddana berarti membangun atau menemukan kota, menjadi beradab, memperbaiki atau memperlakukan secara manusiawi. Kata dayana menjadi kata tamaddun berarti beradab atau peradaban (Ma'luf, 1990). Jadi, orang beragama hendaknya memiliki perilaku santun (beradab) dan menciptakan peradaban, tak menciptakan kekisruhan hanya karena fanatisme sempit.

Perilaku umat beragama di mana pun ada faktor yang andil sebagai modal berperilaku, di antaranya ajaran, fatwa lembaga tinggi agama, pesan leluhur agama, dan kisah hidup umat beragama dalam beragama, karena dalam ajaran agama manapun tentunya mengajak kepada kebaikan (Farihah, 2014, hal. 189). Naskah ini mendalami aspek pesan leluhur agama, yakni Sunan Kudus (anggota walisongo) yang 'mewariskan' ajaran hidup berinteraksi dengan umat Hindu masa itu di Kudus. Warisan tradisi lisan itu kini melegenda menjadi 'fatwa' dalam berpantangan menyembelih sapi karena menghormati hewan yang disucikan dalam agama Hindu. Umat Hindu eksis sebelum era Sunan Kudus hidup di Kudus, meskikini umat Hindu di Kudus hanya ada 12 kepala keluarga. Pewarisan ini dilestarikan oleh warga Nahdliyin (sebagai mayoritas) di Kudus hingga kini yang masih enggan menyembelih sapi, baik untuk ibadah kurban, konsumsi, atau memanfaatkan penyembelihan sapi tatkala mempunyai gawe, seperti mengkhitankan, mengawinkan, dan sejenisnya. Dalihnya, menaati pantangan yang dipantang oleh Sunan Kudus. Walaupun, mengonsumsi daging sapi dengan membeli daging di pasar tradisional bukan menjadi hal tabu bagi Nahdliyin di Kudus. Di Kudus juga ada rumah pemotongan hewan (RPH) yang memotong kerbau dan sapi. Berbeda dengan warga non-Nahdliyin di Kudus yang mentradisikan menyembelih sapi, khususnya tatkala ibadah pada Idul Kurban dengan dalih tak ada dalil nash yang melarang menyembelih sapi.

Mengulas penyembelihan sapi, perlu menampilkan pernyataan Presiden The Hindu Center of Indonesia dari Bali, Dr. Shri I Gusti Ngurah Arya Wedakarna MWS III menjelang Idul Adha 2012 memunculkan polemik. Ia menghimbau agar muslim di Bali tak menyembelih sapi atau kerbau pada bulan Idul Kurban. Dalihnya, semasa Sunan Kudus di Kudus, muslim di Kudus dipantang menyembelihnya karena sapi sebagai hewan disucikan warga Hindu. Sapi merupakan kendaraan Dewa Syiwa. Sebagai bentuk penghormatan, imbuh Wedakarna, sapi diganti jenis hewan lainnya. Desa Adat di Bali pun agar memberi pemahaman pada warga muslim Bali sehingga Bali tetap sakral dan suci. Wacana yang dimuat Tribun News pada 24 Oktober 2012 itu direspon oleh Ketua Bidang Dakwah dan Hubungan Lintas Agama DPP Front Pembela Islam (FPI) Habib Muhsin. Menurut Muhsin, idealnya Wedakarna merumuskan bersama MUI Bali dan tak usah menghimbau atau melarang muslim menyembelih sapi di Bali. Padahal, pada Idul Adha $1432 \mathrm{H}$ umat Hindu di Banjar Margasengkala, Desa Bedudu Kecamatan Blahbatuh Kabupaten Gianyar Bali menyumbangkan seekor sapi untuk dijadikan kurban di lingkungan Masjid Nurul Yaqin. Menurut Muhsin, pelarangan Sunan Kudus masa itu merupakan siasat dakwah. Toleransi harus seimbang, umat Hindu juga harus menghormati keyakinan muslim dalam menyembelih sapi untuk kurban. Menyikapi pro-kontra 
tersebut, menurut penulis, muslim di Pulau Dewata, perlu memikirkan perasaan umat Hindu di Bali, maksudnya hewan yang dikurbankan dalam Islam tak hanya sapi. Dengan demikian, ibadah tetap terlaksana, menjaga perasaan umat Hindu tetap terjaga maka dapat memanfaatkan hewan selain sapi lebih bijaksana, seperti kerbau atau kambing.

Bagi umat Hindu, sapi merupakan lambang ibu pertiwi yang memberikan kesejahteraan kepada semua makhluk hidup di bumi sehingga dihormati, tidak dipuja. Sapi disebut penyangga alam, yakni membantu manusia era tradisional dalam bidang pertanian (membajak), angkutan barang (pedati), dan diperah susunya terutama untuk pertapa (Yogi) dan Maharsi (Nabi). Dalam mitologi dinyatakan bahwa Khrisna sebagai pengembala sejak muda dan sapi disimbolkan sang ibu sehingga dikenal sapi abadi (celestial cow) bernama Kamadhenu. Hal yang dihormati dalam ajaran Hindu meliputi ibu (yang melahirkan), ibu yang menyusui (meski tak mengandung), ibu yang mengasuh (meski tak melahirkan dan tak menyusui), sapi (pemberi sumber panca gavya dalam pengobatan Ayur Vedic), dan ibu pertiwi. Hasil riset ilmiah, urin sapi dan kotorannya mengandung zat antiseptik untuk mengobati penyakit, kotorannya untuk pupuk tanaman. Bagi umat Hindu yang makan daging sapi, wajib hukumnya menyucikan diri (prayascita) dengan mandi sebelum memasuki tempat suci, merenungkan agar tak mengulangi karena ancamannya kelak menderita di neraka selama 100.000 kali 100 tahun. Adapun yang dipuja dalam ajaran Hindu adalah Tuhan (Eko Narayanan Na dwityo Stikascit) dalam bahasa Sanskerta disebut Brahman, dalam bahasa Bali disebut Sang Hyang Widhi Wasa. Brahman sifatnya tak berawal dan tak berakhir, pencipta dan pelebur alam semesta, tak berwujud tertentu dan tak di tempat tertentu, berada dan menyatu pada setiap ciptaan-Nya, terdapat dalam setiap benda apa pun. Tuhan memiliki 8 kekuatan luar biasa (asta aiswarya), yakni serba sangat meliputi halusnya (anima), ringannya (laghima), besar (mahima), menjangkau semua tempat (prapti), melebihi segalanya (isitwa), berkehendak mutlak (prakamya), sangat berkuasa (wasitwa), dan tak dapat diubah (kamawasayitwa). Perlu mendalami muatan Kitab Catur Weda (Rg Weda 10.176.1, Atharwa Weda 3.28.4, Yayur Weda 23.48, dan Sama Weda 176). Sapi disebut ibu (yang menyusui), penyangga alam (memberi kehidupan pada manusia maka disucikan, dihormati, disayangi (tak disembelih, tak dikonsumsi). Dalam perkembangan Hindu di Bali, sapi dibedakan menjadi dua jenis, lembu yang berwarna putih (dapat diperah susunya) dan banteng berwarna merah (tak diperah susunya). Yang dimaksud sapi keramat adalah jenis lembu. Penguat pengeramatan sapi karena mitos dan fanatisme positif.

Dalam konteks kini, umat Hindu di Kudus hanya $12 \mathrm{KK}$ dan mayoritas bukan warga asli Kudus, tapi warga Kudus yang semula pendatang dari Bali dan Klaten Jateng. Di antara mereka, bila mengakhiri hidup, sebagian ingin kembali ke kampung halaman di mana mereka dilahirkan. Pada tataran realitas, apakah dengan memegangi pesan tutur (hingga kini penulis tak menemukan referensi tertulis pelarangan menyembelih sapi oleh Sunan Kudus) berimbas pada perilaku yang toleran pada umat agama lain bagi nahdliyin di Kudus kini? Bagaimana 
mengantisipasi konflik antar-umat beragama di Kudus? Adakah toleransi beragama di Kudus yang kebablasan? Untuk mendapatkan jawaban atas pertanyaan tersebut, riset ini dilakukan. Riset ini diperoleh dengan wawancara, dokumentasi, observasi, forum group discussion (FGD) dengan umat minoritas dan mayoritas dengan analisis deskriptif kualitatif.

\section{Pentingnya Mewujudkan Kerukunan}

Konflik berlatar agama merupakan masalah serius penyebab ketidaknyamanan sosial. Di antara pemicunya adalah persepsi dan pemahaman umat terhadap ajaran agama yang sempit, merasa paling benar dan yang lain salah. Bila terjadi ancaman keamanan wilayah, pimpinan daerah menjadi pemegang kendali. Bila masalah berkecamuk, keamanan dipegang Polri dan dapat meminta bantuan TNI. Grand design penyelesaian konflik dengan tahap jangka pendek, menengah, dan panjang. Tahapan perlu memahami karakter konflik yakni faktor pemicu dan penuntasannya dengan mencari akar persoalan. Perlunya ketegasan pemimpin lokal bersandar pada hukum. Pantura berpijak pada data sejarah, tak luput dari bara konflik yang berpotensi sebagai bahaya laten.

Kerukunan atau rukun merupakan harapan ideal setiap anak manusia, apa pun agamanya. Hal ini dapat terwujud bila teoretis/konsep harmoni dalam interaksi sosial dan empati sosial terwujud. Harmoni interaksi sosial adalah terciptanya keselarasan sosial, manakala dalam bersesama, manusia mengedepankan sifat seimbang (altawazun) kaitannya dengan menerima informasi dari berbagai sumber. Maksudnya, tak latah menghakimi salah, toleran (al-tasamuh) maksudnya memahami dan menghormati di tengah perbedaan, khususnya beda agama atau aliran, dan adil (aladalah) yakni bersikap tegas jika menjadi penguasa dalam menegakkan hukum. Empati sosial adalah kesadaran identitas sosial dalam meningkatkan kapasitas empati sebenarnya dapat dilakukan dengan lebih menambah kesadaran diri (selfaware autonomy) dan mengurangi tendensi mengklaim apa yang benar dan apa yang salah, yang sering muncul dalam symbol agama yang dipahami secara subyektif (Kahmad, 2009, hal. 170). Kesadaran diri/mawas diri bahwa setiap orang memiliki keunikan, kelebihan, dan kekurangan yang dapat saling melengkapi.

\section{Dinamika Tradisi Lisan}

Pangkal akar budaya masyarakat Nusantara tidak lain adalah tradisi lisan. Ketika bangsa Eropa datang dan menyeragamkan pemakaian huruf Latin, tradisi lisan tiba-tiba diafkir dan dipandang usang. Pemakaian huruf Jawi, Pegon, dan huruf lain yang sudah dikenal beberapa etnis di Nusantara seketika terbenam (Mahayana, 2012). Tradisi lisan (Oral Tradition) yang dikenal manusia sebelum budaya tulis adalah budaya cerita (oral). Fungsi budaya oral sebagai media pewarisan nilai dan prinsip tradisi dari generasi ke generasi. Budaya oral melahirkan berbagai syair, puji-pujian, folklor dan lain-lain. Folklor digolongkan dalam tiga bentuk, yakni lisan (legenda, dongeng, petuah adat, nyanyian), lisan dan nonlisan (kepercayaan rakyat, adat-istiadat, permainan), material (arsitektur, busana, 
makanan, kerajinan tangan, kesenian). Dengan pentingnya budaya oral di tengah perkembangan media literasi dewasa ini sebagai bagian dari perkembangan budaya dunia. Unesco mencanangkan Proclamation Masterpieces of the Oral and Intangible Heritage of Humanity at 2001 tujuannya untuk meningkatkan kesadaran tentang warisan budaya nonbendawi. Budaya lisan dan nonbendawi menurut Unesco maksudnya, seluruh kreasi berdasarkan tradisi dari sebuah komunitas kultural yang dinyatakan oleh suatu kelompok atau individu yang mencerminkan identitas sosial dan budaya. Yang termasuk di dalamnya adalah bahasa, sastra, musik, tari, ritual, mitologi, kosmologi, teknik tradisional dalam pembuatan kerajinan tangan, dan ruang-ruang budaya. Unesco mengharapkan agar komunitas budaya di seluruh dunia untuk mengenali, mendokumentasikan, melestarikan, merevitalisasi, dan mempromosikan peninggalan budaya lisan dan nonbendawi. Warisan budaya tak benda (intangible cultural heritage/ICH) dalam Convention for the Safeguarding of the Intangible Cultural Heritage Unesco 2003 adalah praktik, representasi, ekspresi, serta pengetahuan dan keterampilan yang oleh komunitas, kelompok, dan dalam beberapa kasus juga individu mengakui sebagai bagian warisan budayanya bersifat tradisional dan masih dipraktikkan, terus dikreasikan, dan diturunkan ke generasi berikutnya, umumnya secara lisan.

Tradisi lisan (TL) berperan dan berpotensi digunakan menguatkan ketahanan budaya bangsa karena bagian dari kebudayaan. Hidupnya TL cermin hidupnya kebudayaan, sedangkan tangguhnya TL jika tetap hidup dalam komunitasnya, hadir dalam kegiatan masyarakat, dan menjalankan fungsinya dalam konteks kehidupan, terwariskan dalam waktu segenerasi atau antar-generasi. Dikarenakan terbatasnya lingkungan, sejarah lokal lebih terbuka untuk berbagi sumber dan dapat memperkaya penulisan sejarah lokal. Salah satu keunggulan TL adalah kemampuannya mengungkapkan perasaan terdalam dari penuturnya atau dari masyarakat komunitas tradisi tersebut. Cakupan TL tidak hanya dongeng, mite, dan legenda, tetapi lebih luas. Apalagi (terutama masa lalu) masyarakat belum mempunyai tradisi tulisan. Segala pengetahuan dan yang menyangkut sistem kognitif kehidupannya ditransmisikan secara lisan, seperti hukum, UU, kebiasaan, pengobatan, ekspresi kesenian, sistem ekologi, tata cara bermasyarakat, berperilaku, pengajaran, dan yang berkait dengan mata pencaharian. Hal ini disampaikan Pudentia dalam acara sosialisasi draf pedoman penulisan sejarah lokal di Solo, Jateng, September 2005 (Mahayana, 2012).

Mengkaji TL meliputi definisi, aspek, kedudukan, muatan, karakter, ragam, dan bentuk (Endraswara, 2005, hal. 2-9). TL merupakan bagian dari kebudayaan yang diwariskan turun-temurun (secara) lisan sebagai milik bersama dan wujud gagasan kolektif. Keberadaannya sebagai khazanah budaya dan bentuk pancaran pemikiran yang diwariskan oleh leluhur. Tradisi lisan meliputi teknologi tradisional, religi, kesenian rakyat, hukum adat, dsb. Untuk mengetahui sahnya TL jika ada kesaksian lisan yang mengungkapkan masa lalu dengan menekankan unsur kesejarahan. Aspek TL terpilah proses dan produk. Aspek proses adalah pewarisan pesan dari mulut ke mulut sepanjang waktu hingga hilangnya pesan. Aspek produk merupakan 
pesan lisan yang didasarkan pada pesan generasi sebelumnya. Keberadaan TL dapat berkedudukan sebagai sumber informasi, sumber sejarah, dan sumber ajaran yang dijadikan patokan bagi pemeluk agama yang dipegang secara turun-temurun, memiliki ciri khas berupa tak reliabel karena cenderung berubah-ubah, tak ajek, dan rentan perubahan yang dipengaruhi informasi baru dan kreatifitas (pengikut) dalam memahami pesan ajaran yang disesuaikan dengan lingkungan. TL berisi kebenaran terbatas, memuat kebenaran intern, dan tak selalu bersifat universal, dipahami dan diyakini oleh (sebatas) pengikutnya. Kebenaran intern bermakna hanya oleh pengikutnya dan tak dapat diikuti secara universal. Muatan TL memuat aspek historis masa lalu diikuti hingga saat ini oleh kalangan terbatas dan tercipta adanya kesaksian seseorang secara lisan terhadap peristiwa yang bersifat regeneratif dan berkembang (dinamik) sesuai pemahaman yang diterima pemeluknya. Karakter TL terbatas sejauhmana orang dapat mengingat. Hal ini menandakan bahwa tradisi lisan sangat rentan dengan dinamika yang dipengaruhi pemahaman dan kepandaian penyampai tradisi (lisan).

Eksisnya TL mengandalkan faktor kebetulan dan pengulangan kasus yang sama atau karena kepentingan yang terselubung. Misalnya, adanya pengakuan (tim sukses) bahwa pada malam hari terdapat 'bola api' yang menghampiri rumah calon kepala desa tertentu (pertanda kemenangan). Hal itu disosialisasikan dengan harapan memunculkan simpati bagi calon pemilih karena kebenaran tradisi lisan adalah kebenaran dari aspek pengetahuan mistis. Menurut Tafsir (Tafsir, 2004, hal. 112), pengetahuan mistis adalah pengetahuan yang tidak dapat dipahami rasio. Meskipun demikian, masyarakat masih meyakininya karena yang dijadikan ukuran bersifat batin, subjektif, dan nonlogis. Adakalanya TL yang terkikis karena pola pikir masyarakat yang (mengarah) rasional, seperti pantangan jika orang masih hidup dibelikan fasilitas kematian. Sebagian masyarakat masa kini, hal tersebut mengalami pergeseran menjadi tidak tabu karena faktor kondisi. Sebagai contoh rencana membeli sebidang tanah makam, jika tidak segera dibeli (meskipun (calon) penghuni makam masih hidup), tanah tersebut akan dibeli oleh pihak lain, sehingga jika bertakziyah harus meluangkan waktu tambahan, dampaknya rasa tabu tersebut tergeser oleh realitas.

Ragam tradisi lisan terpilah interaksi lisan, karya estetis lisan, dan pedoman hidup lisan, sedangkan yang dikategorikan interaksi lisan berupa dongeng (cerita yang tidak benar-benar terjadi), legenda (cerita rakyat pada zaman dulu yang ada hubungannya dengan peristiwa sejarah), mite yakni cerita yang berlatar belakang sejarah, dipercayai masyarakat sebagai cerita yang benar-benar terjadi, dianggap suci, banyak mengandung hal-hal yang ajaib, dan umumnya ditokohi oleh dewa. Sedangkan mitologi adalah ilmu tentang bentuk sastra yang mengandung konsepsi dan dongeng suci mengenai kehidupan dewa dan makhluk halus di suatu kebudayaan, (Depdiknas, 2008, hal. 922) fabel (cerita yang menggambarkan watak dan budi manusia yang pelakunya diperankan binatang), anekdot (cerita singkat yang menarik karena lucu dan mengesankan, biasanya berdasarkan kenyataan), teka-teki, arsitektur tradisional, pantun (peribahasa sindiran), syair (puisi lama 
yang tiap baitnya terdiri 4 baris yang berakhir dengan bunyi yang sama), dan hikayat. Hal tersebut dikenal istilah folklor, yakni cabang ilmu antropologi yang memelajari berbagai bentuk kebudayaan yang diwariskan turun-temurun secara lisan atau dikenal cerita rakyat (dongeng, legenda, hikayat,dll) sebagai khazanah budaya masa silam yang luhur, mengandung pelajaran berharga tentang kehidupan, misalnya keimanan, ketakwaan, kejujuran, kesombongan,dsb. yang relevan dengan kehidupan sekarang karena yang membedakan dengan masa silam hanyalah fasilitas atau lingkungan alam dan sosial.

Menurut Danan, ciri folklor meliputi (1) penyebaran dan pewarisannya secara lisan, disebarkan dari mulut ke mulut dan dari generasi ke generasi, (2) bersifat tradisional yakni disebarkan dalam bentuk relatif tetap dan dalam waktu yang lama (paling sedikit dua generasi), (3) keberadaannya dalam versi yang berbeda karena penyebaran via mulut ke mulut, (4) bersifat anonim (penciptanya sudah tidak diketahui), (5) mempunyai bentuk berpola, penggunaan kata klise, dan ungkapan lama (seperti anuju sakwijining dino), (6) berfungsi dalam kehidupan bersama, seperti pelipur lara, alat pendidikan, protes sosial, dan proyeksi terpendam, (7) bersifat pralogis yakni mempunyai logika sendiri, tidak sesuai dengan logika umum, (viii) milik bersama, bersifat polos dan lugu (Danandjaya, 1984, hal. 3). Menurut J.H Brunvand (1968) terdapat tiga tipe folklor yakni folklor lisan (verbal folklore), folklor sebagian lisan, dan folklor bukan lisan (nonverbal folklore). Bentuk folklor lisan (i) bahasa rakyat (folk speech) seperti logat, julukan, pangkat tradisional, dan titel kebangsawanan, (ii) ungkapan tradisional, seperti peribahasa, pepatah, dan pemeo, (iii) pertanyaan tradisional, seperti teka-teki, (iv) puisi rakyat, seperti pantun, gurindam, dan syair, (v) cerita prosa rakyat, seperti mite, legenda, dan dongeng, dan (vi) nyanyian rakyat. Sedangkan folklor bukan lisan adalah folklor yang bentuknya bukan lisan, pembuatannya secara lisan dipilah dua, materiil dan bukan materiil. Yang materiil seperti arsitektur rumah adat atau rakyat, pakaian dan perhiasan tubuh adat, masakan dan minuman adat, dan obat-obatan tradisional. Yang nonmateriil seperti isyarat tradisional (gesture), bunyi isyarat untuk komunikasi rakyat (kentongan tanda bahaya di Jawa) meskipun hal ini telah bergeser, atau bunyi gendang untuk mengirim berita di Afrika, dan musik rakyat.

Folklor sebagian lisan (partly verbal folklore) adalah folklor yang bentuknya merupakan campuran unsur lisan dan bukan lisan, meskipun cara penyampaiannya secara lisan, seperti kepercayaan rakyat (folk belief) dan ada yang menganggap takhayul (superstitious). Contoh tanda salib bagi umat Katolik dianggap dapat melindungi gangguan hantu. Bagi orang Jawa dapat berupa akik, rajah, dsb. Menurut Brunvand (1968) takhayul mengandung kepercayaan (belief), kelakuan (behaviour), kebiasaan, pengalaman (experience), alat, dan sajak yang diwariskan melalui tutur kata dengan syarat (i) adanya tanda (sign), misal, suara katak (tanda) maka akan turun hujan (akibat/result), (ii) sebab akibat (causes) menurut hubungan asosiasi, dengan syarat adanya persamaan (a) waktu (misal, suara burung hantu di malam hari diduga ada kematian atau pencuri), (b) wujud (jika perempuan hamil makan pisang dempet maka anak yang dilahirkan akan dempet), (c) totalitas dan 
bagian, serta (d) bunyi sebutan (bagi seorang pengusaha asal Tegal, larangan makan anggur dikhawatirkan menganggur, dan (iii) berakibat (result). Adapun folklor lisan Indonesia berupa bahasa rakyat, ungkapan tradisional, pertanyaan tradisional (Pertanyaan bersifat tradisional mempunyai jawaban tradisional pula, seperti tekateki), sajak dan puisi rakyat, nyanyian rakyat, dan cerita prosa rakyat (Danandjaya, 1984, hal. 3).

Menurut penulis, folklor lisan Indonesia dipengaruhi pesan agama. Begitu pula munculnya penghormatan terhadap tokoh/leluhurnya, seperti sebagian warga Kota Kudus meyakini/penghormatan kepada Sunan Kudus dengan (i) tidak membuat tempat tidur tingginya melebihi tingginya (bangunan) makam Sunan Kudus, (ii) 'pantangan' bagi pejabat agar tidak melewati pintu masuk makam Sunan Kudus, diyakini memiliki 'rajah kolocokro', (iii) pejabat pusat/Jakarta 'dipantangkan' memasuki Kota Kudus, jika melanggar dikhawatirkan lengser dari jabatannya. Meskipun semasa menjabat sebagai Presiden RI periode 2004-2009, Presiden SBY mengadakan kunjungan kerja di Kabupaten Pati dan Rembang, Jawa Tengah melewati Kabupaten Kudus, walaupun tidak mampir di pendopo Kabupaten Kudus yang bersiap diri menerima kunjungannya. Kunjungan 9 Juni 2009 pada musim kampanye dirinya menuju Presiden RI periode 2009-20014 berpasangan dengan Wapres Boediono, (iv) pantangan warga seputar menara Kudus (Kudus Kulon) agar tidak menanam tanaman yang menjalar/menggantung, seperti sayur gambas, labu/waluh atau yang dientik, (v) pantangan bagi warga Kota Kudus untuk tidak memotong sapi sebagai bentuk mengikuti jejak Sunan Kudus masa lalu menghormati umat Hindu yang berpantangan menyembelih sapi/lembu pada 10 Dzulhijjah (Idul Kurban), dan (vi) pantangan warga Kudus yang mendirikan rumah adat kudus menghadap ke utara (menghadap Gunung Muria), dan masih banyak lagi tradisi lisan yang 'terpendam' oleh dinamika kehidupan.

Bentuk tradisi lisan terpilah bentuk primer dan sekunder. Bentuk primer bermakna tradisi belum bersentuhan dengan tradisi baru, sedangkan bentuk tradisi lisan sekunder adalah tradisi telah disentuh oleh tradisi baru. Sebagaimana contoh tradisi lisan primer dalam masyarakat Jawa (khususnya wilayah Pantura) yang bertebaran secara lisan. Kebenarannya spekulatif (kadang benar dan kadang kala bertolak-belakang) karena tidak adanya pijakan dan argumen pengokoh. Munculnya tradisi lisan tersebut berlandaskan daya ingat yang (pernah) terjadi dan (pernah) terulang. Sehingga setiap wilayah (Jawa) tidak selalu sama dalam memberikan pemahaman terhadap tradisi berikut ini. Seperti (a) jago berkokok (Jawa: kluruk) belum waktu yang lazim, pertanda ada perawan yang hamil. Lazimnya jago berkokok setelah dini hari hingga menjelang pagi hari, (b) kupu yang multiwarna memasuki rumah, pertanda akan kedatangan tamu orang yang disayangi, (c) kupu warna putih memasuki rumah, pertanda kedatangan tamu (yang tidak selalu) diharapkan, (d) burung malam berkicau dan bertalu-talu, pertanda akan ada warga yang meninggal dunia, (e) mata berdenyut-denyut atau makan tersengguk, pertanda sedang digunjing, (f) kucing mengeong pertanda akan hujan, dsb. Adapun bentuk tradisi lisan sekunder seperti relief yang tertuang dalam ukiran jati produk industri 
kayu dari kota ukir, Jepara, Jateng yang diminati buyer di antaranya diilhami oleh cerita rakyat, Ramayana dan Baratayudha. Begitu pula motif batik Kota Kudus yang diminati peminat di antaranya yang menggoreskan mode kapal karam, sebuah cerita rakyat yang mengisahkan perseteruan antara Sunan Kudus dengan Saudagar dari China, Dampoawang yang dimenangkan Sunan Kudus.

Analisis Paeni, pewarisan budaya berlaku sebagai proses sosial dan umumnya secara lisan, sebelum orang mengenal budaya tulis. Tradisi lisan antara lain narasi, legenda, anekdot (Legenda adalah cerita rakyat masa dulu yang ada hubungannya dengan peristiwa sejarah atau tokoh terkenal. Anekdot merupakan cerita singkat yang menarik karena lucu dan mengesankan, biasanya mengenai orang penting atau terkenal dan berdasarkan kejadian sebenarnya), pantun (peribahasa sindiran) atau syair. Dalam cakupan yang luas, dapat berupa pembacaan sastra, visualisasi sastra dengan gerakan dan tari, penyajian cerita melalui aktualisasi adegan oleh pemeran. Tradisi lisan berkaitan sistem kognitif masyarakat seperti adat-istiadat, sejarah, etika, sistem geneologi, dan sistem pengetahuan yang dijadikan sumber inspirasi untuk menciptakan produk kreatif. Disampaikan Mukhlis Paeni, Pembina Asosiasi Tradisi Lisan dan Staf Ahli Menteri bidang Pranata Sosial, Departemen Pariwisata dan Kebudayaan, dalam Seminar Internasional Tradisi Lisan Nusantara ke-VI dan Festival Tradisi Lisan Maritim di Wakatobi, Sulawesi Tenggara, 1-3 Desember 2008 (Mahayana, 2012).

Menurut Pudentia Maria Purenti, TL membuktikan warga mampu beradaptasi dengan perubahan dan keberagaman. Meskipun TL belum sepenuhnya dimanfaatkaan saat konflik antarkelompok. TL merekam ingatan masyarakat atas kemampuan beradaptasi. Saat ini terjadi anomali karena persepsi dijadikan acuan, bukan ingatan, sehingga terjadi penyeragaman karena persepsi sekelompok orang atau golongan. Ingatan merupakan acuan penetapan identitas. Adapun persepsi menentukan sikap dan gerak. Menurut Ayu Sutarto, pelestarian TL membutuhkan kerja sama pewaris aktif (pelaku) dan pasif (penikmat) (Dinyatakan Pudentia dan Ayu pada seminar Tradisi Lisan di Tanjung Pinang, Kepulauan Riau (Kepri), 26 Mei 2012 (Mahayana, 2012). Kesaksian lisan merupakan unsur yang perlu dijadikan telaah khusus dengan pertimbangan terbatasnya person yang dijadikan saksi lisan. Kesaksian dipengaruhi kepiawaian penutur lisan dalam hal daya memori (daya ingat) terhadap peristiwa sejarah masa lalu, (kadangkala) person tersebut enggan dijadikan sumber sejarah karena trauma sejarah atas diri, kelompok, atau diri dan kelompok. Hal ini berdampak tertutupnya akses kesaksian lisan. Begitu pula kelihaian penggali sumber data melalui wawancara yang berobyekkan tradisi lisan diharuskan memahami role of game yang tepat.

\section{Perilaku Umat Beragama di Kudus}

Perilaku umat beragama di Kudus yang tergambarkan dalam naskah ini merupakan bentuk aktivitas yang tak dominan. Meskipun demikian, aktivitas itu bila tidak dievaluasi akan merambah menjadi tradisi yang tak bijak. Data yang terdokumentasikan oleh penulis menggambarkan bahwa (oknum) muslim di Kudus 
(pernah) berperilaku tak etis terhadap umat seagama dan agama lain.

Pertama, penutupan tempat ibadah yang juga rumah hunian/lahan bisnis dengan dalih tak menaati aturan dalam SKB Menag dan Mendagri. Pendirian tempat ibadah di Desa Getas Pejaten, Kecamatan Jati yang memanfaatkan rumah toko (ruko) di gedung Ipiems jalan Agus Salim yang dipimpin pendeta F. Iskandar Wibawa. Peribadatan dihentikan warga karena dianggap salah fungsi dan direspon Bupati Kudus menerbitkan surat Nomor 450/7777/11/2006 tanggal 23 November 2006 ditandatangani Asisten Tata Praja, Suyono. Isi surat menghentikan penggunaan ruko sebagai tempat ibadah.

Digunakannya rumah Sukarjo untuk ibadah di Dukuh Conge Rt.5/II, Desa Ngembalrejo, Kecamatan Bae, Kudus. Inisiatif Forum Umat Islam Ngembal (FUIN) melayangkan surat keberatan tanggal 30 April 2010 ditembuskan pada Muspida Kudus dan Muspika Bae. Surat ditandatangani 30 ormas dan 1.387 warga Desa Ngembalrejo. FUIN meminta penghentian aktivitas keagamaan dan membongkar rumah yang dijadikan gereja. Difasilitasi Forum Koordinasi Pimpinan Daerah (Forkominda) Bae, 5 Mei 2010 dialog antara pemilik rumah, yayasan, dan masyarakat di Balai Desa Ngembalrejo. Disepakati menutup sementara kegiatan kebaktian kristiani dan mengurus izin rumah ibadah sesuai peruntukan dan selama belum terbit izin tak diperbolehkan digunakan aktivitas keagamaan. Walaupun keberadaan FUIN hanya tatkala ada persoalan itu. Kini rumah tak lagi difungsikan untuk peribadatan umat Kristen.

Kedua, Jamaah Dzikrussholikhin dipimpin Nur Rokhim RT.06/01 Desa Golantepus, Kecamatan Mejobo. Sang tokoh karena teguhnya zikir dan salat malam secara rutin, ia mengaku bertemu malaikat. Suatu malam, ditemui cahaya mengajak ruhnya singgah di rumah mewah. Oleh Rokhim, cahaya tersebut dianggap malaikat dan oleh tetangganya Rokhim dianggap sesat. Aparat desa dan kepolisian 2 September 2007 memfasilitasi kedua belah pihak di balai desa bahwa pengajian dihentikan. Penggalian data penulis, pemicu utama adalah ketersinggungan tokoh lokal dengan banyaknya santri Rokhim dari luar daerah yang berdzikir rutin di rumahnya. Padahal, (anggapan tokoh lokal tetangga Rokhim), ia tak pernah nyantri. Hanya saja, Rokhim karena kemiskinannya riyadloh dan mendapatkan jalan terang hingga direspon para santri.

Ketiga, pengajian di musala milik Sariyono warga Rw.4 Desa Pasuruan Lor, Kecamatan Jati memanas pada Kamis 10 Februari 2011. Persoalannya, dakwah setiap Minggu dan Kamis malam oleh Sariyono menggunakan empat pengeras suara yang hanya dihadiri 5 orang. Dakwah juga dipancarkan di radio dengan frekuensi 06.35 MHz. Materi yang didakwahkan menghujat dengan menyebut nama yang dihujat dan tokoh agama. Pernyataan lainnya, seseorang bisa disebut ulama bila pernah ditemui Nabi SAW. Bahkan menurutnya, seseorang ditemui Nabi SAW merupakan hak Nabi tanpa memandang seorang yang rajin beribadah atau tidak. Agar ketegangan tak meluas, melalui rapat yang difasilitasi Kepala Desa, pengeras suara dan pemancar radio dibongkar dengan pengawalan aparat kepolisian dan TNI. 
Keempat, Majelis Tafsir Al-Quran (MTA) pada 28 Januari 2012 mengadakan louncing pembukaan cabang di Kudus yang dihadiri dari warga MTA se-Jateng. Akan tetapi, dibubarkan oleh ormas Islam di Kudus karena dianggap mengkritik pedas. Tetapi, pascapembubaran, pengajian rutin MTA di Kudus tetap eksis dan data yang digali penulis, ustad MTA tak lagi menampakkan kritik nakalnya pada tradisi NU.

Kelima, tatkala Pilkades di Desa Colo, Kecamatan Dawe tahun 1998, sang kiai sekaligus guru mengaji mencalonkan diri sebagai peserta Pilkades. Tetapi, adanya ancaman melalui tim suksesnya, bagi warga yang pernah mengaji pada sang kiai (yang juga pecalon pilkades) dan tak memilih sang kiai maka ilmunya tak akan bermanfaat. Pernyataan ini direspon negatif oleh sebagian warga. Dalih warga, ilmu yang telah diberikan tentunya tanpa tendensi politik. Kekecewaan ini direspon oleh rival pilkades lain untuk dijadikan pendukungnya. Tetapi, karena pemenang pilkades adalah sang kiai maka gerakan membaikot dilakukan oleh kelompok tertentu dalam bentuk mendirikan pengajian rutin antar-anggota jamiyah baru. Kekecewaan itu direspon oleh mubaligh Ahmadiyah hingga mendirikan Cabang Ahmadiyah di Kudus hingga kini dengan 12 KK. Kondisi Jemaat Ahmadiyah Indonesia (JAI) beraliran Lahore di Kudus, hasil riset penulis, kondisinya ibarat api dalam sekam, yang rentan konflik. Padahal sebelumnya kondisi Desa Colo sangat kondusif (Rosyid, 2014, hal. 91).

Kelima kasus tersebut hingga kini, penulis tak menemukan fakta konflik agama, baik terselubunh maupun terbuka yang diderita umat Hindu. Hal ini dikarenakan jumlah umat Hindu di Kudus yang hanya $12 \mathrm{KK}$, peribadatannya tidak terpublikasi sehingga tak muncul respon dari publik.

Hal yang perlu dipahami muslim di Kudus bahwa semakin dilarang memanfaatkan tempat untuk beribadah, semakin militan pula umat minoritas dalam beragama. Hal ini terjadi karena adanya pihak yang memperlakuan tak bijak sehingga muncul kesadaran untuk kompak dalam beragama. Dengan demikian, perlunya mewarisi perilaku Nabi SAW dalam bertoleransi. Pemikiran moderat dalam kenegaraan dicontohkan Nabi SAW dalam Piagam Madinah (PM) atau Konstitusi Madinah yang ditetapkan pada $622 \mathrm{M} / 1 \mathrm{H}$. PM merupakan konstitusi negara tertulis pertama di dunia, mendahului Magna Charta di Inggris dan mendahului Konstitusi Amerika dan Perancis. Konstitusi PM diawali "Bismillahirrahmanirrahim. Haadza kitaabun min Muhammadin Nabi Shallahualaihi wa sallam. Bainal mukminin wal muslimin min quraisiyyin wa yatsriba wa man tabiahum falahiqa bihim wa jaahada ma'ahum (Dengan nama Allah yang Maha Pengasih dan Maha Penyayang. Inilah piagam tertulis dari Nabi SAW kepada orang mukmin dan muslim, baik dari Suku Quraisy maupun Yatsrib dan kepada segenap warga yang ikut bersama mereka, yang telah membentuk kepentingan bersama dengan mereka telah berjuang bersama mereka). Pasal 16 "Sesungguhnya bangsa Yahudi yang setia kepada Negara (kita) berhak mendapat bantuan dan perlindungan, tak boleh dikurangi haknya dan tak boleh diasingkan dari pergaulan umum. Pasal 24 "Warga Negara dari Yahudi memikul biaya bersama-sama dengan mukmin, selama negara dalam peperangan". 
Pasal 25 "(1) Kaum Yahudi dari suku Banu 'Auf adalah satu warga negara dengan muslim, (2) Kaum Yahudi bebas memeluk agama mereka dan muslimin bebas memeluk agamanya, (3) kebebasan ini berlaku juga terhadap pengikut/sekutunya, (4) kecuali berbuat jahat yang menimpa dirinya dan keluarganya. Kesadaran hidup di tengah masyarakat yang berbeda akidah oleh Al-Quran ditegaskan dalam al-Mumtahanah:8 "Allah tak mencegahmu berbuat baik kepada mereka (nonmuslim) yang tak memerangimu dan tak mengusirmu dari kampungmu." Nabi SAW berpesan "Barang siapa menyakiti seorang kafir $d z i m m i$ (non-muslim yang tak melawan muslim) sungguh ia menyakitiku (Nabi SAW) (H.R Thabrani). Barang siapa yang membunuh seorang manusia (bukan karena orang yang dibunuh itu pembunuh), bukan perusak bumi, maka seakan-akan (yang membunuh itu) telah membunuh manusia seluruh alam. Bagi yang memelihara kehidupan seorang manusia maka seolah-olah dia telah memelihara kehidupan manusia semuanya (alMaidah:32). Jikalau Allah menghendaki, niscaya Dia menjadikan kamu sat umat (saja) tetapi Allah menyesatkan siapa yang dikehendaki-Nya dan memberi petunjuk kepada siapa saja yang dikehendaki-Nya. Sesungguhnya kamu akan dimintai pertanggungjawaban atas apa yang telah diperbuat (an-Nahl:93). Sikap toleran juga dilanjutkan oleh Umar bin Khattab yang melakukan perjanjian Aelia dengan kaum Kristen di Yerussalem pada 636 M. Kemenangan Umar atasnya di Yerussalem, Umar tetap menghormatinya.

Toleransi dilakukan pula kunjungan Imam Besar Al-Azhar, Mesir, Syekh Ahmad Muhammad Ahmad Ath-Thayyeb di Vatikan bertemu dengan Paus Franciscus Senin 23 Mei 2016 setelah lima tahun keduanya berhubungan dingin. Hal ini akibat lontaran Paus Benekdiktus XVI yang meminta perlindungan lebih bagi umat Nasrani yang berada di Mesir. Hal ini dipicu kerusuhan malam Tahun Baru 2010 di gereja Kristen Coptic di Kota Alexandria, Mesir, umat Nasrani tewas 21 orang. Dengan bertemunya tokoh utama dan diikuti warga awam di arus bawah diawali dengan dialog antaragama, srawung secara alami, saling percaya, saling menghormati dengan kerendahan hati dan difasilitasi pemerintah maka toleransi sejati berpijak dari karya nyata mampu mengurangi tensi ketegangan pemicu konflik.

\section{Toleransi di Kudus yang Kebablasan}

Adapun yang dimaksud dengan toleransi kebablasan adalah sikap cuek (tak hirau) nya umat Islam menghadapi perilaku muslim lainnya yang menjadi teroris. Teroris tersebut tewas di tangan Densus 88 Mabes Polri dan dimakamkan di Kudus, meski sudah bukan lagi warga Kudus, hanya saja keluarganya ada yang di Kudus. Embrio teroris dan jaringannya diduga masih bercokol di Kudus, sebagaimana pemakaman teroris yang tewas oleh aparat dan dimakamkan di Kudus. Dalihnya, keluarganya ada di Kudus.

Pertama, Agus Budi Pranoto (alias Urwah) lahir di Kudus 2 November 1978, ia tertembak Densus 88 bersama Noordin M Top, Aris Sudarso dan Susilo di Kampung Kepuhsari Rt.3/11, Mojosongo, Jebres, Solo pada 16 September 2009 
dan dimakamkan di Kudus. Proses pemakaman Urwah bersitegang antarwarga Dukuh Klisat Rt.8/I, Desa Mijen, Kaliwungu. Pelaku bom Kedubes Australia 2004 divonis 7 tahun penjara, setelah bebas, tertembak di Solo pada 16 September 2009. Sebelumnya Urwah tersangka bom Hotel JW Marriott dan Ritz Carlton pada 17 Juli 2003 (buronan bersama Syaifuddin Zuhri, M.Syahrir, dan Sudarso) dan sembunyikan Azhari dan Noordin M.Top, divonis 3 tahun 6 bulan akhirnya bebas. Sejak Januari 2007 Urwah menjadi warga Dukuh Bantarejo Rt.1/IV, Desa Kadokan, Grogol, Sukoharjo kawin dengan Rina Yudi Astuti, sebagai dai di masjid Al-Hikmah, Dukuh Buntarejo, sebelumnya mengajar bahasa Arab pada 1998 (setahun) di Ponpes Islam Nurul Huda Dukuh Kedung Jampang Karangreja, Kutasari, Purbalingga. Respon warga Kudus terhadap pemakaman Urwah muncul pro-kontra difasilitasi Kades dan BPD Mijen beserta Muspika Kaliwungu. Keluarga Urwah menandatangani surat pernyataan bermaterai bahwa keluarga menjamin keamanan dan melarang kelompok jamaah dari Solo melayat, tak memasang spanduk/karangan bunga bertuliskan pahlawan jihad atau tulisan pemicu konflik. Penolakan pemakaman dimotori Karangtaruna dan BPD Mijen serta MUI Kudus dengan alasan Urwah bukan lagi penduduk Kudus dan khawatir desa dicap sebagai sarang teroris yang melanggar prinsip Islam, menyimpang akidah, dan pembunuh. Alternatifnya pemerintah diharap mencarikan tempat pemakaman Urwah yang bebas konflik. Bagi yang menerima pemakaman di Kudus berdalih mayat wajib dimakamkan, apapun statusnya asal jenazah muslim dimakamkan layaknya muslim dan Urwah masih dianggap asli warga Kudus, akhirnya dimakamkan di Kudus.

Kedua, pemakaman Bayu Setianto (alias Harun, 30 tahun) dan Zainuri, kedua teroris ditembak Densus 88 di Kebumen pada 8 Mei 2013. Bayu warga Desa Hadipolo, Jekulo, Kudus semula ditolak pemakamannya di Hadipolo karena keluarga menyerahkan pemakaman pada Tim Pembela Muslim, warga menghendaki pemakaman oleh pihak desa. Pada 24 Mei 2013 jenazah dimakamkan di Hadipolo. Tak bedanya jenazah Zainuri warga Desa Klumpit Rt.1/5, Gebog, Kudus akhirnya dimakamkan di Klumpit pada 1 Juni 2013. Antara perjanjian prapemakaman dengan realitas tak sama karena yel-yel menganggap teroris laksana pahlawan menjadi pemandangan baru pemakaman di Kudus. Idealnya Kudus tak lagi menjadi sarang pemakaman teroris jika ingin nihil dari konflik. Ada pula teroris disergap Densus 88, Abu Thalut pada 10 Desember 2010 di Dukuh Pondok Rt.4/3, Desa Bae, Kecamatan Bae, Kudus. Setelah proses hukum dan selesai ditahan, kini menetap di Kudus. Adapun Eka Zumi Astuti, mahasiswi warga Kudus Rt 4/IV Desa Jati Kulon, Jati, Kudus (diduga) korban NII, pernah ditahan Mapolrestabes Semarang.

Kenyamanan hidup warga merupakan kebutuhan primer menjadi tanggung jawab negara berpijak pada UU Nomor 7 Tahun 2012 tentang Penanganan Konflik Sosial. Pasal 10 Pemerintah dan Pemda membangun sistem peringatan dini (SPD) untuk mencegah konflik di daerah yang diidentifikasi sebagai daerah potensi konflik; dan/atau perluasan konflik di daerah yang sedang konflik. SPD berupa penyampaian informasi mengenai potensi konflik atau terjadinya konflik melalui media komunikasi. Pasal 11 membangun SPD penelitian dan pemetaan wilayah potensi 
konflik secara cepat akurat; penyelenggaraan diklat; peningkatan dan pemanfaatan modal sosial; dan penguatan dan pemanfaatan fungsi intelijen. Aspek lain yang lebih penting adalah ulama menjadi pelerai konflik dengan mendatarkan ajaran Islam yang toleran terhadap minoritas, tak berpikir tekstual, idealnya kontekstual yakni ajaran agama tak dipahami sepotong-potong tapi dengan modal lapang dada. Perbedaan SARA merupakan desain Tuhan. Perbedaan menjadi saling sayang (rahmah) antarsesama yang sama dan berbeda jika saling memahami perbedaan. Ibarat kebun raya, tak indah bila hanya ada satu bunga atau satu warna bunga, tapi beragam warna menjadi indah dipandang. Pada konteks sosial, perbedaan SARA ditakdirkan Ilahi (sunnatullah/hukum alam).

Penyulut terjadinya konflik antar-umat beragama di negeri ini dipicu oleh fanatisme umat beragama yang mengiblat pada ketidaktegasan pemerintah dalam menegakkan hukum. Bahkan terkesan lebih pro yang mayoritas atau pemilik modal. Dengan demikian, yang perlu dibangun adalah nalar berpikir positif dan kesadaran bersesama antar-warga bangsa meski berbeda agama atau kepercayaan. Media yang digunakan untuk membangun nalar positif tersebut adalah lembaga pendidikan formal dan non-formal. Begitu pula peran Lembaga Swadaya Masyarakat (LSM) atau Nation Government Organization (NGO) dalam memberikan pendampingan pada masyarakat, dan perlunya dikokohkan pendirian komunitas lintas-tokoh agama dan kepercayaan dengan argumen: Pertama, toleransi antar-umat beragama masih semu. Indikatornya, mayoritas publik beranggapan bahwa bertetangga lebih nyaman dengan seagama, kecuali ikatan persaudaraan atau bawahan-atasan. Hal ini dapat dijembatani bila antar-tokoh agama saling mengenal pada level awal kalangan tokoh agama hingga memahami. Harapannya muncul saling menyadari bahwa sesama manusia meski beda akidah/agama tetap saling membutuhkan. Untuk mewujudkannya, perlu jalan panjang. Pesimisme yang dihadapinya, adanya anggapan bahwa upaya toleransi akan sia-sia karena antar-tokoh tak siap bergabung. Realitanya, hal itu secara perlahan akan mencair dengan modal kesadaran bersama. Kedua, masih adanya lembaga pendidikan 'berbendera' agama tak menanamkan sikap toleransi karena hari libur nasional agama lain, tetap masuk sekolah. Keberadaan komunitas menjembatani ketimpangan realitas. Ketiga, antara umat beragama dengan umat penghayat kepercayaan keduanya belum saling menyadari adanya perbedaan keyakinan. Hal ini perlu dicairkan bahwa berbeda tak untuk dipaksakan sama. Perbedaan adalah anugerah Tuhan untuk disyukuri, tak untuk dibasmi. Potensi ragam agama dan aliran di Nusantara merupakan potensi khazanah budaya yang diwariskan leluhur untuk diuri-uri. Ibarat taman, ragam warna dan bentuk bunga merupakan esensi keindahan taman itu sendiri. Bila taman hanya satu warna dan satu bentuk bunga, alangkah tak indahnya taman itu. Prinsipnya saling mengenal, peduli, dan merasakan antar-umat beragama agar tercipta toleransi antar-umat beragama, ternafikan kecurigaan, dan terantisipasi bila terjadi konflik.

Untuk mewujudkan perdamaian, perlu memahami pedoman etika hubungan sosial antar-umat beragama dengan prinsip (1) egalitarianisme (al-musawat), yakni memandang manusia dilahirkan sama derajatnya, (2) prinsip keadilan (al-adalat), yakni tidak diskriminatif, (3) toleran (tasamuh) maksudnya, menghargai, (4) ko- 
eksistensi damai (al-ta'asyusy al-silmi), dan (5) dialog arif-konstruktif-transformatif, konsekuensi dari keempat prinsip (Naim, 2011, hal. 54-55).

\section{Simpulan}

Faktor penyebab pergeseran makna toleransi beragama (pantangan penyembelihan sapi) di Kudus akibat pola pikir masyarakat Kudus yang terdidik dari jenjang pendidikan formal, santri yang terdidik pada pendidikan formal, generasi muda yang menegakkan secara utuh pesan quran dan hadis, dan ketidaktahuan masyarakat Kudus yang hidup kini bahwa sapi pada masa Sunan Kudus menjadi pamali jika disembelih. Keempat faktor tersebut penyebab utama pergeseran makna toleransi beragama yang semula tidak menyembelih sapi karena masyarakat Kudus (saat itu) memeluk agama Hindu yang mengeramatkan sapi. Kini masyarakat Kudus dalam jumlah minoritas pemeluk Hindu dan jika sapi disembelih pun bukan bentuk ketidaktoleransian beragama.

Kesadaran beragama dengan umat seagama atau beda agama yang terhindar dari konflik perlu kebersamaan dan sepenanggungan hidup antar elemen sosial. Perlu berpijak pada pesan Nabi SAW terdapat 4 sendi stabilitas dunia, ilmunya ulama (cendekiawan, intelektual), keadilan penguasa, kedermawanan orang mampu, doanya fakir miskin. Bila salah satu sendi tak berfungsi, yang terjadi adalah instabilitas dalam kehidupan. Ulama sebagai pewaris keilmuan pendahulu yang adiluhung, bertugas mengajak (mengingatkan) pada publik menuju jalan kebajikan dan meninggalkan jalan kemunkaran dengan fatwa dan ide yang ditulisnya. 


\section{Referensi}

Danandjaya, J. (1984). Folklor Indonesia Ilmu Gosip, Dongeng, dan Lain-lain. Jakarta: Grafiti.

Depdiknas. (2008). Kamus Besar Bahasa Indonesia. Jakarta: Pusat Bahasa.

Endraswara, S. (2005). Lisan Jawa Warisan Abadi Budaya Leluhur. Yogyakarta: Narasi.

Farihah, I. (2014). Agama Menurut Ibn Khaldun. Fikrah: Jurnal Ilmu Aqidah dan Studi Keagamaan, 2(1), 187-205.

Kahmad, D. (2009). Sosiologi Agama. Bandung: Remaja Rosdakarya.

Mahayana, M. (2012, Januari 8). Jembatan Kelisanan dan Keberaksaraan. Kompas. Jakarta.

Manzhur, I. (2005). Lisan al-Arab. Cairo: Maktabah Turast al-Arabi.

Ma>luf, L. (1990). Munjid. Beirut: Dar al-Fikr.

Naim, N. (2011). Teologi Kerukunan Mencari Titik Temu dalam Keragaman. Yogyakarta: Teras.

Rosyid, M. (2014). Keselarasan Hidup Beda Agama dan Aliran: Interaksi Nahdliyin, Kristiani, Buddhis, dan Ahmadi di Kudus. Fikrah: Jurnal Ilmu Aqidah dan Studi Keagamaan, 2(1), 75-94.

Tafsir, A. ( $\vdash \varepsilon)$. Filsafat Ilmu. Bandung: Rosda Karya. 